\title{
FORMULATION AND EVALUATION OF STATISTICALLY DESIGNED IBUPROFEN FAST- DISSOLVING TABLETS EMPLOYING STARCH GLUTAMATE AS A NOVEL SUPERDISINTEGRANT
}

\author{
SANTOSH KUMAR R*, SAHITHI MUDILI \\ Department of GITAM Institute of Pharmacy, GITAM (Deemed to be University), Visakhapatnam, Andhra Pradesh, India.
}

Email: drsantoshrada@gmail.com

Received: 10 August 2019, Revised and Accepted: 16 September 2019

ABSTRACT

Objective: The main aim of the present work is to enhance the solubility and bioavailability of the ibuprofen by formulating it into fast-dissolving tablets employing starch glutamate as a novel superdisintegrant.

\begin{abstract}
Materials and Methods: Starch glutamate was prepared from native potato starch and glutamic acid by the esterification process. Drug-excipient compatibility studies were performed between the starch glutamate and ibuprofen with the help of Fourier transform infrared spectroscopy, and differential scanning calorimetry techniques. Ibuprofen fast dissolving tablets were formulated employing different superdisintegrants along with the starch glutamate (a novel superdisintegrant) by the direct compression method. The prepared ibuprofen fast-dissolving tablets were evaluated for various pre- and post-compression parameters along with the in vitro and in vivo release characteristics. Optimized formulation stability studies were performed at accelerated conditions for 6 months as per the International Conference on Harmonization (ICH) and WHO guidelines.
\end{abstract}

Results: Drug-excipient compatibility studies indicated that prepared starch glutamate was compatible with ibuprofen drug, and it can be used as a superdisintegrant in the formulation of fast-dissolving tablets. Fast-dissolving tablets of ibuprofen were formulated by employing starch glutamate as a superdisintegrant showed good tablet properties and showed an increased dissolution efficiency of the drug. Among all the formulations (F1-F8), the formulation $\mathrm{F} 4$ which contains $5 \%$ starch glutamate and $5 \%$ croscarmellose sodium as superdisintegrants showed $99.7 \pm 0.34 \%$ drug dissolution within 5 min. Peak plasma concentration of optimized formulation F2 was achieved in a short period of time and increased relative bioavailability and F2 was found to be stable during accelerated stability testing as per the ICH stability guidelines.

Conclusion: From drug-excipient compatibility studies, disintegration time, in vitro dissolution studies, and pharmacokinetic studies, it was concluded that starch glutamate can be used as a superdisintegrant in the formulation of fast-dissolving tablets to increase the solubility as well as bioavailability of the poorly soluble drugs.

Keywords: Starch glutamate, Drug interactions, In vitro and in vivo studies, Factorial design, International Conference on Harmonization-stability.

(c) 2019 The Authors. Published by Innovare Academic Sciences Pvt Ltd. This is an open access article under the CC BY license (http://creativecommons. org/licenses/by/4. 0/) DOI: http://dx.doi.org/10.22159/ajpcr.2019.v12i11.35308

\section{INTRODUCTION}

Ibuprofen is a nonsteroidal anti-inflammatory drug BCS Class-II drugs, having low solubility and high permeability [1]. Ibuprofen is used in the treatment of rheumatoid and osteoarthritis. Ibuprofen is most widely used to treat dental pain and orofacial pain [1]. Ibuprofen is a poorly soluble drug, having bioavailability problems. The solubility of poorly soluble drugs can be enhanced by formulating them into fastdissolving tablets employing superdisintegrants. Superdisintegrant aids in faster disintegration of the tablet into smaller particles and enhancing the effective surface area to, which results in improved solubility, rate of absorption and bioavailability of the poorly soluble drugs [2].

In the present investigation, bioavailability of ibuprofen drug was increased by formulating it as fast-dissolving tablets employing a novel superdisintegrant, i.e., starch glutamate which was synthesized from native potato starch by esterification. Drug-excipient compatibility between the ibuprofen and starch glutamate was evaluated by Fourier transform infrared spectroscopy (FTIR), and differential scanning calorimetry (DSC) techniques. The direct compression technique was employed in formulation of fast dissolving tablets of ibuprofen. Precompression and post-compression parameters of the prepared fastdissolving tablets were evaluated and optimized using $2^{3}$ factorial design, in which concentration of superdisintegrants, i.e.,, starch glutamate (A), croscarmellose sodium (B), and crospovidone (C) was independent variables and dissolution efficiency in $5 \mathrm{~min}$ and percent dissolved in 5 min were dependent variables. To the optimized formulation pharmacokinetic studies and stability studies were performed as per the International Conference on Harmonization (ICH) stability guidelines.

\section{MATERIALS AND METHODS}

Procurement of materials

Glutamic acid, potato starch, acetone, hydrochloric acid, potassium dihydrogen phosphate, dimethyl sulfoxide, crospovidone, croscarmellose sodium, mannitol, and microcrystalline cellulose were purchased from the SD fine chemicals, Hyderabad, and ibuprofen drug purchased from Yarrow Chem, Mumbai.

\section{Preparation of starch glutamate}

Initially, the starch slurry was prepared by weighing 10 parts of potato starch accurately and dispersing it into the beaker containing 25 parts of distilled water. To this starch slurry, 10 parts of glutamic acid were added to make a dispersion. The dispersion $\mathrm{pH}$ was adjusted to 3.5 by adding $10 \mathrm{ml}$ of sodium hydroxide to it later the dispersion was conditioned for $16 \mathrm{~h}$ without any disturbance by allowing complete reaction between glutamic acid and potato starch. The dispersion was filtered, and the filtrate was washed with distilled water after conditioning to remove unreacted glutamic acid, then this solid mass was dried at $60^{\circ} \mathrm{C}$, which results in the formation of starch glutamate. After drying, starch glutamate was passed through \#120 sieve to get uniform particle size distribution and stored in a desiccator. 
Drug-excipient compatibility study

The compatibility between the starch glutamate and selected drug, i.e., ibuprofen was evaluated by FTIR and DSC studies.

\section{FTIR}

Starch glutamate and ibuprofen mixture 1:1 ratio was taken and measured in the Bruker FTIR (Tokyo, Japan) at 4000-500 $\mathrm{cm}^{-1}$ to know the compatibility between the starch glutamate and ibuprofen drug [3].

DSC

DSC thermograms of the starch glutamate and ibuprofen (1:1) mixture were analyzed in Perkin Elmer Thermal analyzer at a heating rate of $10^{\circ} \mathrm{C} \mathrm{min}^{-1}$ and temperature range of $30-350^{\circ} \mathrm{C}$ to know the compatibility between the starch glutamate and ibuprofen drug [3].

\section{Formulation of ibuprofen fast-dissolving tablets}

Ibuprofen fast-dissolving tablets were formulated by direct compression method $^{5}$. In the formulation of fast-dissolving tablets of ibuprofen, concentrations of superdisintegrants selected were based on $2^{3}$ factorial statistical design. In 23 factorial statistical design, three (concentration of superdisintegrants) were independent variables and two (dissolution efficiency in $5 \mathrm{~min}$ and percent dissolved in $5 \mathrm{~min}$ ) were the dependent variables. The superdisintegrants are in two levels; one is lower level, i.e., zero and another is higher level, i.e., $5 \%$ concentration. All the ingredients were passed through the \#100 mesh to attain uniformity in particle size. All the ingredients are mixed geometrically after accurate weighing and mixed thoroughly in a mortar with the help of the pestle. The blend of powder was compressed into tablets in eight-station tablet compression machine (Karnavati Machineries Pvt., Ltd., Ahmedabad, India). Formulae of ibuprofen fast-dissolving tablets employing starch glutamate are given in Table 1.

\section{Evaluation tests of ibuprofen fast-dissolving tablets Hardness test}

Hardness of the ibuprofen fast dissolving tablets was evaluated by calculating the average breaking point of 10 tablets with the help of the Monsanto Hardness Tester. In this, each tablet was placed in the hardness tester, then applied the force and recorded the breaking point [5].

\section{Friability test}

The friability of the ibuprofen fast-dissolving tablets was performed in the Roche friabilator. Initially, 20 tablets were de-dusted and weighed. The previously weighed tablets were placed in the friabilator drum and rotated at 25 RPM for 100 revolutions. After completion of revolutions, again tablets were weighed and calculated the percent weight loss using the following formula [5].

$$
\mathrm{F}=100 \times \frac{[\mathrm{W}(\text { initial })-\mathrm{W}(\text { final })]}{\mathrm{W}(\text { initial })}
$$

\section{Drug content uniformity test}

Content uniformity of ibuprofen fast-dissolving tablets was determined by estimating the assay or purity of ibuprofen tablets with the help of ultraviolet-visible (UV-Vis) spectrophotometer. In this, 10 tablets were weighed accurately and powdered; from this, powder containing $10 \mathrm{mg}$ weight of ibuprofen (equivalent) was taken and diluted with the help of $7.2 \mathrm{pH}$ phosphate buffer to obtain a series of dilutions. These dilutions absorbance was measured using UV-Vis spectrophotometer at $222 \mathrm{~nm}$ [5].

\section{Wetting time}

Wetting time of the ibuprofen fast-dissolving tablets was determined by placing the tablet on the tissue paper placed in the Petri dish containing $10 \mathrm{ml}$ of amaranth solution. Time taken by the amaranth solution to reach the surface of the tablet was noted as wetting time of the tablet [5].

\section{Water absorption ratio}

The water absorption ratio of ibuprofen fast-dissolving tablets was determined by placing the tablet on the double-folded Whatman filter paper in a Petri dish containing distilled water. Before performing the test, initial weight of the tablet was noted, then the tablet was allowed to wet completely. The later weight of the wetted tablet was noted. The water absorption ratio of the ibuprofen fast-dissolving tablets was calculated using the following formula [5].

$$
\mathrm{R}=100 \frac{\mathrm{W}_{\mathrm{d}}-\mathrm{W}_{\mathrm{e}}}{\mathrm{W}_{\mathrm{e}}}
$$

Where

$\mathrm{R}=$ Water absorption ratio; $\mathrm{W}_{\mathrm{d}}=$ Weight of the tablet after water absorption; $\mathrm{W}_{\mathrm{e}}=$ Weight of the tablet before water absorption.

\section{In vitro disintegration time}

In vitro disintegration time of the ibuprofen fast dissolving tablets was determined using the USP disintegration apparatus, containing basket rack assembly. $\mathrm{pH} 7.2$ phosphate buffer acts as a disintegration medium. Six tablets were randomly selected from each formulation batch and placed in disintegration apparatus. Disintegration test was performed by maintaining the disintegration media temperature at $37 \pm 0.2^{\circ} \mathrm{C}$ and basket rack assembly was allowed to move up and down through a distance of 5-6 cm at a frequency of 28-32 cycles/min. Time taken for the complete disintegration of the tablet without leaving any residue was noted as disintegration time [5].

\section{In vitro dissolution studies}

In vitro dissolution studies of ibuprofen fast dissolving tablets were performed using USP type - II dissolution apparatus, i.e., paddle apparatus. Dissolution study was performed in the 8 stations Electro TDL-8 L dissolution apparatus which were fitted with paddle. $\mathrm{pH} 7.2$ phosphate buffer was used a dissolution medium by maintaining temperature at $37 \pm 0.5^{\circ} \mathrm{C}$. Ibuprofen fast-dissolving tablets were placed in $900 \mathrm{ml}$ dissolution media, and paddle speed was adjusted to 50 RPM. Samples were withdrawn at predetermined time intervals, and absorbance was measured in the UV-vis spectrophotometer (Shimadzu) at $222 \mathrm{~nm}$, to estimate the cumulative percentage of drug dissolution [5].

\section{Factorial design}

A statistical analysis was conducted to know the optimum formulation with suitable superdisintegrant having the highest percentage of drug

\begin{tabular}{|c|c|c|c|c|c|c|c|c|}
\hline Ingredients (mg/tablet) & F1 & F2 & F3 & F4 & F5 & F6 & F7 & F8 \\
\hline Ibuprofen & 200 & 200 & 200 & 200 & 200 & 200 & 200 & 200 \\
\hline Starch glutamate (A) & - & 25 & - & 25 & - & 25 & - & 25 \\
\hline Croscarmellose sodium (B) & - & - & 25 & 25 & - & - & 25 & 25 \\
\hline Crospovidone $(\mathrm{C})$ & - & - & - & - & 25 & 25 & 25 & 25 \\
\hline Mannitol & 30 & 55 & 55 & 30 & 55 & 30 & 30 & 5 \\
\hline Microcrystalline cellulose & 200 & 200 & 200 & 200 & 200 & 200 & 200 & 200 \\
\hline Talc & 10 & 10 & 10 & 10 & 10 & 10 & 10 & 10 \\
\hline Total weight & 500 & 500 & 500 & 500 & 500 & 500 & 500 & 500 \\
\hline
\end{tabular}

Table 1: Formulae of ibuprofen fast-dissolving tablets 
release in $5 \mathrm{~min}$ and the highest percent of dissolution efficiency in $5 \mathrm{~min}$. A polynomial regression algorithm equation was drawn by correlating the independent variables like concentration of superdisintegrants, i.e.,, starch glutamate (A), croscarmellose sodium (B), and crospovidone (C) and response variables such as dissolution efficiency in $5 \mathrm{~min}$ and percent dissolved in $5 \mathrm{~min}$. Contour plots and surface response plots were plotted with the help of Design Expert 7.11 version software to know the interaction effects of the level of each factor in the dissolution efficiency in $5 \mathrm{~min}$ and percent dissolved in $5 \mathrm{~min}$ [4].

In vivo studies

In vivo pharmacokinetic parameters of the optimized ibuprofen fastdissolving tables were evaluated by performing the in vivo studies on the male Wistar rats. The optimized formulation of ibuprofen fastdissolving formulation containing starch glutamate was given orally to the male Wistar rats along with the pure drug. These pre-clinical studies were conducted after getting approval from the Institutional Animal Ethical Committee, GITAM Institute of Pharmacy, GITAM (Deemed to be University), and Visakhapatnam (Approval No: 1287/PO/Re/S/09/ CPCSEA). 200-250 g body weight of male Wistar rats was selected for the pre-clinical studies. These Wistar rats were housed in a wire cage with access to food and water. These cages were placed in a clean room with controlled temperature of $20-25^{\circ} \mathrm{C}$ and by maintaining complete $12 \mathrm{~h}$ light and dark cycles [6]

Male Wistar rats with body weight 200-250 g selected randomly and divided into two groups, each group containing six rats. In two groups, one group treated with ibuprofen pure drug (10 mg/Kg in $0.5 \% \mathrm{CMC}$ ) and another group was treated with ibuprofen optimized formulation prepared by employing starch glutamate (10 mg/Kg in 0.5\% CMC). Before conducting the study, rats were fastened for $12 \mathrm{~h}$ and during the study, they had limited access to food and water. Two-way crossover design was selected for the study. The dose was administered to the Wistar rats by dispersing the drug in distilled water and through the oral feeding pipe. After drug administering, blood samples were collected from lateral tail vein of the rat at specified time intervals, i.e., zero (pre-dose), $0.5,1,2,3,4,5,6,7$, and $8^{\text {th }} \mathrm{h}$ by anesthetizing the rats with mild ether. These blood samples were collected in the microcentrifuge tubes which contain $6 \mathrm{mg}$ of ethylenediaminetetraacetic acid (anticoagulant) to prevent the blood clotting in micro centrifuged tubes. Plasma from these blood samples was separated by centrifugation at a speed of 5000 RPM for $25 \mathrm{~min}$, and these plasma samples were stored at $-20^{\circ} \mathrm{C}$ until further analysis. These plasma samples were analyzed using a validated high-performance liquid chromatography method to determine pharmacokinetic parameters.

\section{Stability studies}

Shelf life of optimized formulation of ibuprofen fast-dissolving tablets by employing starch glutamate was determined by storing the samples at a temperature of $40 \pm 2^{\circ} \mathrm{C}$ and $75 \pm 5 \% \mathrm{RH}$ for 6 months as per accelerated stability testing guidelines specified in the ICH and WHO. These stability samples were analyzed for any change in the physical properties and drug release characters after storing them for 6 months [7].

\section{RESULTS AND DISCUSSION}

FTIR spectrum of ibuprofen pure drug and ibuprofen-starch glutamate is given in Figs. 1 and 2. In the FTIR spectrum of ibuprofen pure drug characteristic bands were observed at $2956.42 \mathrm{~cm}^{-1}, 2871.52 \mathrm{~cm}^{-1}$, $1720.28 \mathrm{~cm}^{-1}$, and at $1420.22 \mathrm{~cm}^{-1}$ whereas same characteristic bands were observed at $2955.46 \mathrm{~cm}^{-1}, 2871.75 \mathrm{~cm}^{-1}, 1719.55 \mathrm{~cm}^{-1}$, and $1419.89 \mathrm{~cm}^{-1}$ in the FTIR spectrum of ibuprofen-starch glutamate. FTIR spectrums indicate that starch glutamate was compatible with the selected drug and does not exhibit any drug interactions.

DSC thermograms of the ibuprofen and ibuprofen-starch glutamate are shown in Figs. 3 and 4. DSC thermograms of the ibuprofen $\left(79.77^{\circ} \mathrm{C}\right)$ and ibuprofen-starch glutamate $\left(79.02^{\circ} \mathrm{C}\right)$ exhibited the sharp exothermic peaks at melting point of the ibuprofen, i.e., $75-80^{\circ} \mathrm{C}$. From

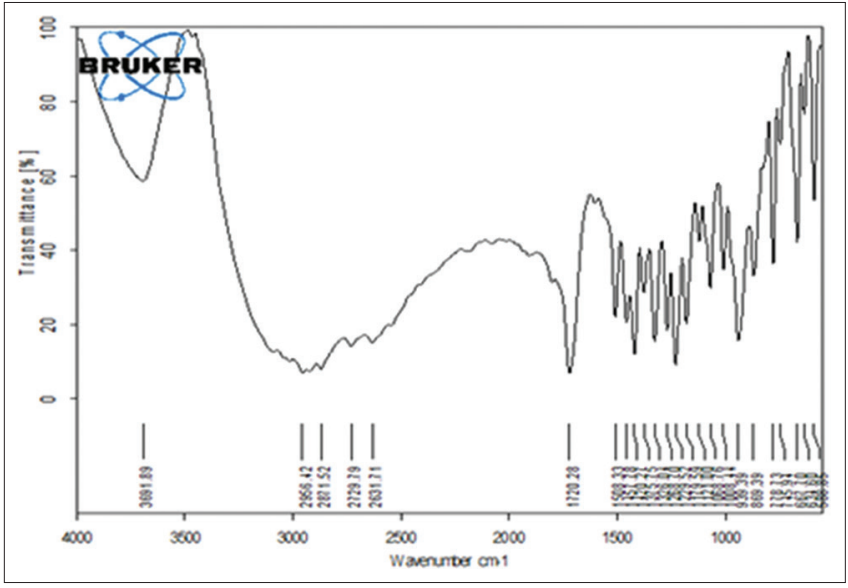

Fig. 1: Fourier transform infrared spectrum of ibuprofen pure drug

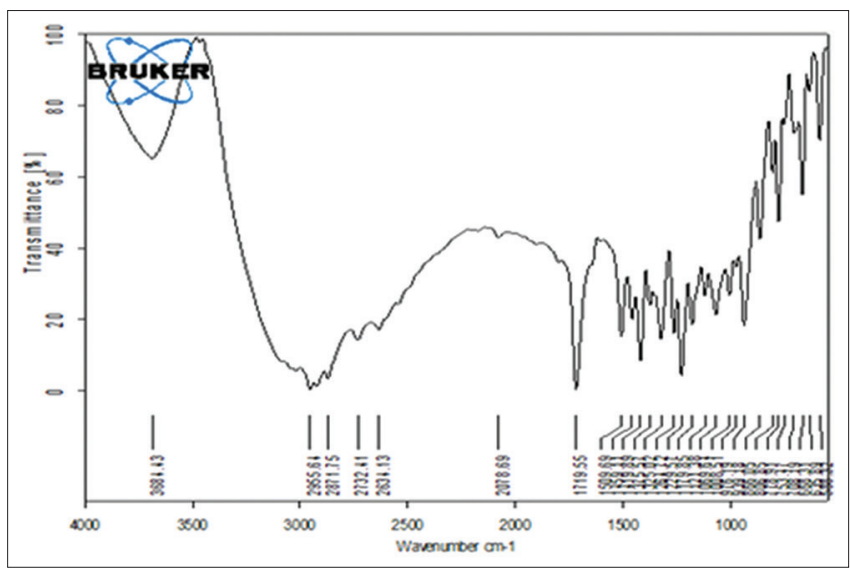

Fig. 2: Fourier transform infrared spectrum of ibuprofen starch glutamate

DSC thermograms, we can conclude that the starch glutamate was compatible with the drug.

\section{Tablets evaluation tests Hardness}

The fast-dissolving tablets of ibuprofen passed the official Indian Pharmacopoeia (IP) hardness test. Hardness of the fast-dissolving tablets of ibuprofen was found to be in between $3.7 \pm 0.02$ and $3.9 \pm 0.02 \mathrm{Kg} / \mathrm{cm}^{2}$. From these results, it was concluded that the tablets which were prepared by employing starch glutamate as a superdisintegrant possess sufficient mechanical strength to resist the pressure during handling, packing, and transportation. Hardness test results are given in Table 2.

\section{Friability}

The fast-dissolving tablets of ibuprofen passed the official IP friability test by having the friability $<1 \%$. The friability of fast-dissolving tablets of ibuprofen was in the range of $0.11 \pm 0.011 \%-0.13 \pm 0.014 \%$. From these results, it was known that the fast-dissolving tablets of ibuprofen were strong enough to withstand pressure during packing and transportation. Friability test results are given in Table 2.

\section{Drug content uniformity}

The fast-dissolving tablets of ibuprofen passed the official IP drug content uniformity test by having the drug content in the range of $85-115 \%$ of average content. Drug content results of the ibuprofen fast-dissolving tablets were found to be in between $198.12 \pm 0.14$ and $199.69 \pm 0.32 \mathrm{mg} / \mathrm{tab}$. From these results, it was concluded that all the 


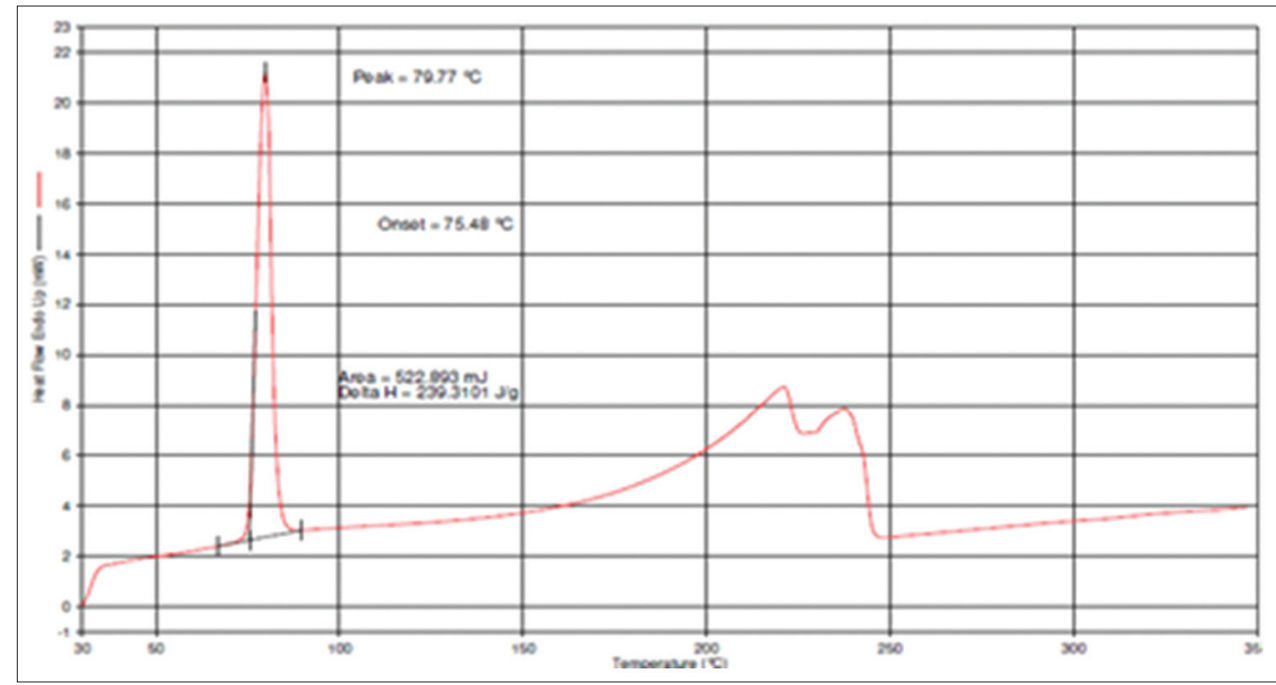

Fig. 3: Differential scanning calorimetry thermogram of ibuprofen pure drug

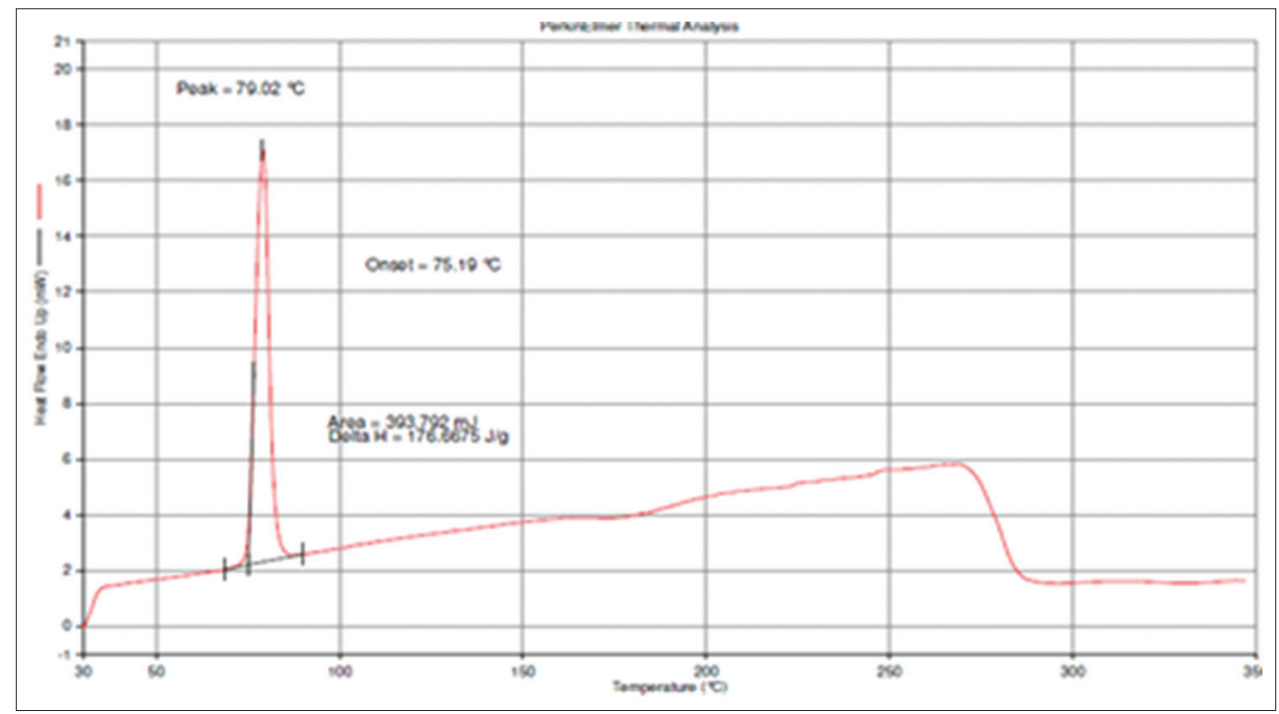

Fig. 4: Differential scanning calorimetry thermogram of ibuprofen starch glutamate

Table 2: Physical properties of ibuprofen fast-dissolving tablets

\begin{tabular}{|c|c|c|c|c|c|c|}
\hline Formulation & $\begin{array}{l}\text { Hardness } \\
\left(\mathrm{kg} / \mathrm{cm}^{2}\right) \mathrm{n} \pm S D\end{array}$ & $\begin{array}{l}\text { Friability (\%) } \\
\mathrm{n} \pm \mathrm{SD}\end{array}$ & $\begin{array}{l}\text { Drug content } \\
(\mathrm{mg} / \mathrm{tab}) \mathrm{n} \pm \mathrm{SD}\end{array}$ & $\begin{array}{l}\text { Wetting } \\
\text { time (s) } n \pm S D\end{array}$ & $\begin{array}{l}\text { Water absorption } \\
\text { ratio }(\%) n \pm S D\end{array}$ & $\begin{array}{l}\text { Disintegration } \\
\text { time (s) } n \pm S D\end{array}$ \\
\hline F1 & $3.8 \pm 0.02$ & $0.11 \pm 0.011$ & $199.69 \pm 0.32$ & $182 \pm 1.53$ & $0.20 \pm 0.002$ & $365 \pm 1.0$ \\
\hline $\mathrm{F} 2$ & $3.9 \pm 0.01$ & $0.12 \pm 0.011$ & $199.21 \pm 0.31$ & $9 \pm 0.58$ & $2.22 \pm 0.001$ & $21.3 \pm 1.5$ \\
\hline F3 & $3.8 \pm 0.02$ & $0.13 \pm 0.014$ & $198.12 \pm 0.14$ & $5 \pm 0.00$ & $0.23 \pm 0.002$ & $8 \pm 0.0$ \\
\hline F4 & $3.9 \pm 0.01$ & $0.11 \pm 0.012$ & $199.11 \pm 0.45$ & $4 \pm 0.58$ & $0.51 \pm 0.006$ & $9 \pm 0.0$ \\
\hline F5 & $3.8 \pm 0.01$ & $0.13 \pm 0.011$ & $199.21 \pm 0.32$ & $3 \pm 0.00$ & $0.73 \pm 0.002$ & $22 \pm 1.0$ \\
\hline F6 & $3.7 \pm 0.02$ & $0.12 \pm 0.013$ & $199.56 \pm 0.45$ & $3 \pm 0.00$ & $0.97 \pm 0.003$ & $5 \pm 0.0$ \\
\hline F8 & $3.9 \pm 0.02$ & $0.11 \pm 0.014$ & $199.41 \pm 0.13$ & $4 \pm 0.00$ & $1.18 \pm 0.001$ & $25.3 \pm 0.6$ \\
\hline
\end{tabular}

*All the values are expressed as mean \pm SD, where $n=3, S D$ : Standard deviation

fast-dissolving tablets of ibuprofen contain a uniform amount of drug. Drug content uniformity results are tabulated in Table 2.

\section{Wetting time and water absorption ratio}

Wetting time and water absorption ratio of the ibuprofen fast dissolving tablets depended on the superdisintegrants employed in them. The ibuprofen fast-dissolving formulation which contains superdisintegrants has the less wetting time and more water absorption ratio as compared to the formulation with no superdisintegrants. The descending order of wetting time for the ibuprofen fast-dissolving tablets was found to be $\mathrm{F} 1>\mathrm{F} 2>\mathrm{F} 7>\mathrm{F} 3>\mathrm{F} 4>\mathrm{F} 8>\mathrm{F} 5>\mathrm{F} 6$, whereas ascending order of the water absorption ratio of ibuprofen fast-dissolving tablets were found to be $\mathrm{F} 1<\mathrm{F} 3<\mathrm{F} 4<\mathrm{F} 5<\mathrm{F} 6<\mathrm{F} 7<\mathrm{F} 8<\mathrm{F} 2$. Wetting time and water absorption ratio results are given the Table 2 .

\section{In vitro disintegration time}

Disintegration time of the ibuprofen fast-dissolving tablets depended on the concentration of the superdisintegrants which were employed in 
Table 3: Cumulative percentage of ibuprofen dissolved $(n \pm S D)$

\begin{tabular}{llllllll}
\hline Time & F1 & F2 & F3 & F4 & F5 & F6 & F7 \\
\hline 5 & $15.0 \pm 0.75$ & $77.1 \pm 2.43$ & $99.4 \pm 0.51$ & $99.7 \pm 0.34$ & $84.2 \pm 0.96$ & $99.0 \pm 0.11$ & $87.3 \pm 1.40$ \\
10 & $17.3 \pm 1.01$ & $99.1 \pm 1.15$ & - & - & $99.8 \pm 0.30$ & - & $85.6 \pm 1.45$ \\
15 & $28.9 \pm 0.65$ & - & - & - & - & - & - \\
30 & $45.3 \pm 1.05$ & - & - & - & - & - & - \\
45 & $52.9 \pm 0.66$ & - & - & - & - & - & - \\
60 & $74.2 \pm 1.04$ & - & - & - & $-1.1 \pm 0.56$ & $-1 \pm 0.46$ \\
\hline
\end{tabular}

*All the values are expressed as mean \pm SD, where $n=3$, SD: Standard deviation

Table 4: Dissolution parameters of the ibuprofen fast dissolving tablets formulated using starch glutamate as a superdisintegrant (n \pm SD)

\begin{tabular}{|c|c|c|c|c|c|c|c|c|}
\hline Time (mins) & F1 & F2 & F3 & F4 & F5 & F6 & F7 & F8 \\
\hline $\mathrm{PD}_{5}$ & $15.0 \pm 0.75$ & $77.1 \pm 2.43$ & $99.4 \pm 0.51$ & $99.7 \pm 0.34$ & $84.2 \pm 0.96$ & $99.0 \pm 0.11$ & $87.3 \pm 1.40$ & $85.6 \pm 1.45$ \\
\hline $\mathrm{DE}_{5}^{5} \%$ & $11.7 \pm 1.45$ & $75.6 \pm 1.90$ & $95.7 \pm 1.17$ & $97.1 \pm 0.12$ & $83.2 \pm 0.74$ & $96.0 \pm 0.81$ & $84.0 \pm 1.18$ & $84.0 \pm 2.00$ \\
\hline $\begin{array}{l}\text { No of folds increase } \\
\text { in } \mathrm{DE}_{5} \%\end{array}$ & - & 6.46 & 8.17 & 8.29 & 7.11 & 8.20 & 7.17 & 7.17 \\
\hline $\mathrm{K}_{1}\left(\mathrm{~min}^{-1}\right)$ & $0.020 \pm 0.001$ & $0.539 \pm 0.136$ & $1.174 \pm 0.390$ & $1.378 \pm 0.426$ & $0.695 \pm 0.208$ & $0.921 \pm 0.022$ & $0.141 \pm 0.022$ & $0.583 \pm 0.119$ \\
\hline $\begin{array}{l}\text { No of folds increase } \\
\text { in } K_{1}\left(\mathrm{~min}^{-1}\right)\end{array}$ & - & 26.95 & 58.7 & 68.9 & 34.75 & 46.05 & 7.05 & 29.15 \\
\hline
\end{tabular}

All the values are expressed as mean \pm SD, where $n=3$, SD: Standard deviation. $\mathrm{PD}_{5}$ : Percent dissolved in 5 min, $\mathrm{DE}_{5} \%$ : Dissolution efficiency in 5 min, $\mathrm{K}_{1}$ : First-order rate constant

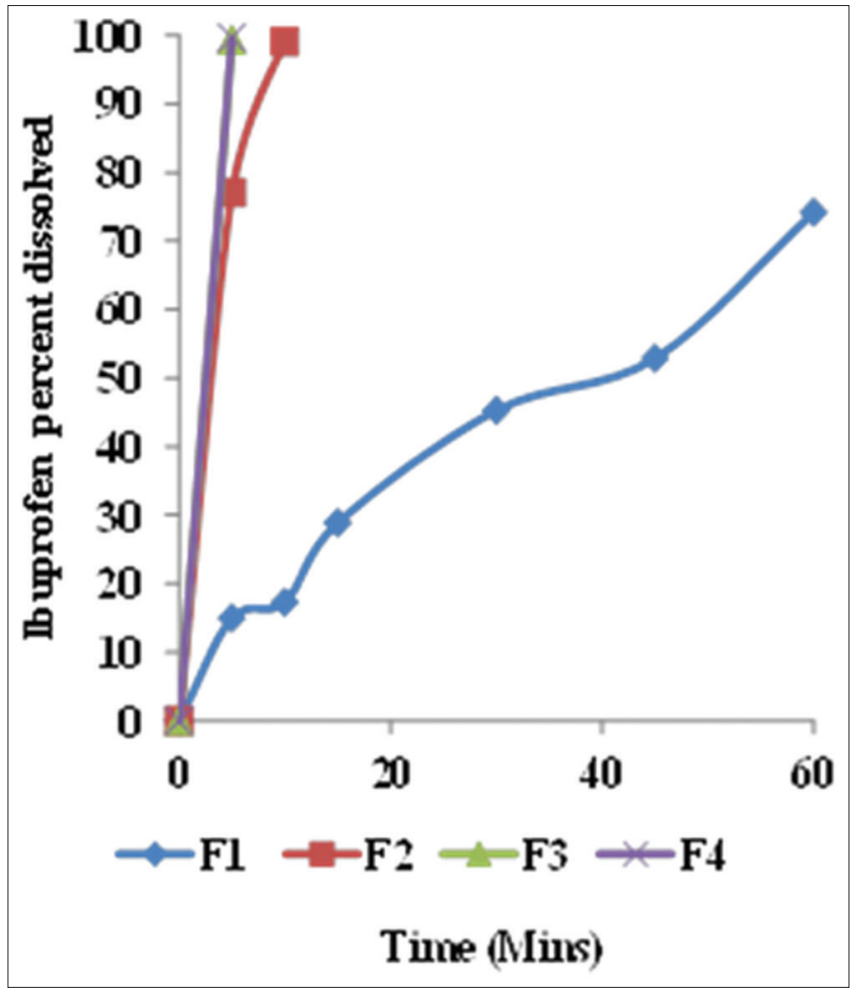

Fig. 5a: Dissolution profile of ibuprofen fast-dissolving tablets prepared by employing starch glutamate (F1-F4) $(n=3$, mean \pm standard deviation)

the formulation. In vitro disintegration time of ibuprofen fast-dissolving tablets was in the range of $365 \pm 1.0-5 \pm 0.0 \mathrm{~s}$. Among all the formulation, the formulation F6 which contains $5 \%$ of starch glutamate and crospovidone as superdisintegrants showed least disintegration time, i.e., $5 \pm 0.0 \mathrm{~s}$, whereas the in vitro disintegration time of the formulation F2 containing 5\% starch glutamate as a superdisintegrant is also comparable with the F6. In vitro disintegration time results of the ibuprofen fast-dissolving tablets are given in Table 2.

In vitro dissolution studies

In vitro drug dissolution from the ibuprofen fast-dissolving tablets depended on the concentration of the superdisintegrants which were

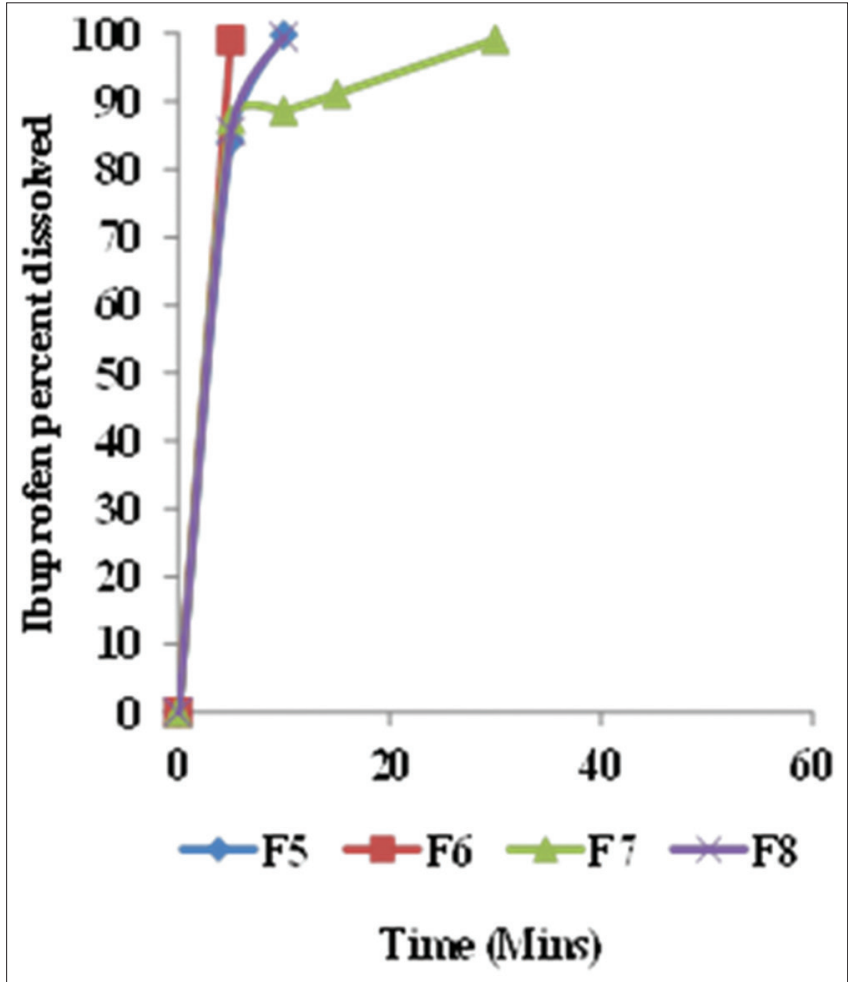

Fig. 5b: Dissolution profile of ibuprofen fast-dissolving tablets prepared by employing starch glutamate (F5-F8) (n=3, mean \pm standard deviation)

employed in the formulation. The rate of dissolution was directly proportional to the concentration of the superdisintegrants. The cumulative percentage of drug release and dissolution parameter results of ibuprofen fast-dissolving tablets is given in Tables 3 and 4 and represented in Figs. $5 \mathrm{a}$ and b, 6a and b. From the results, it was concluded that the ibuprofen fast-dissolving formulation F4 which contains $5 \%$ starch glutamate and 5\% croscarmellose sodium as superdisintegrants showed $99.7 \pm 0.34 \%$ drug dissolution within $5 \mathrm{~min}$. Formulation F4 is considered as good fast-dissolving formulations of ibuprofen which was found to better than the ibuprofen fast-dissolving tablets formulated by Kumar et al. [8]. 
Table 5: ANOVA of disintegration time of ibuprofen fast-dissolving tablets formulated by employing starch glutamate

\begin{tabular}{|c|c|c|c|c|c|}
\hline Source of variation & d.f & Sum of squares & Mean S.S & Variance ratio & Result \\
\hline Replicates & 2 & 5.58 & 2.79 & 4.64 & $\mathrm{P}>0.05$ \\
\hline Treatments & 7 & 318702.96 & 45528.99 & 75701.42 & $\mathrm{p}<0.05$ \\
\hline Starch glutamate (A) & 1 & 50508.38 & 50508.38 & 83980.68 & $\mathrm{p}<0.05$ \\
\hline Croscarmellose sodium (B) & 1 & 42926.04 & 42926.04 & 71373.46 & $\mathrm{p}<0.05$ \\
\hline Starch glutamate $\times$ Croscarmellose sodium (AB) & 1 & 47082.04 & 47082.04 & 78283.68 & $\mathrm{p}<0.05$ \\
\hline Crospovidone (C) & 1 & 38001.04 & 38001.04 & 63184.63 & $\mathrm{p}<0.05$ \\
\hline Starch glutamate $\times$ Crospovidone (AC) & 1 & 38001.04 & 38001.04 & 63184.63 & $\mathrm{p}<0.05$ \\
\hline $\begin{array}{l}\text { Starch glutamate } \times \text { Croscarmellose } \\
\text { sodium } \times \text { Crospovidone }(A B C)\end{array}$ & 1 & 42084.38 & 42084.38 & 69974.03 & $\mathrm{p}<0.05$ \\
\hline Error & 14 & 8.42 & 0.60 & - & - \\
\hline Total & 23 & - & - & - & - \\
\hline
\end{tabular}

All the values are expressed as mean \pm SD, where $n=3$, SD: Standard deviation. d.f: Degree of freedom, ${ }^{*}$ S.S: Sum of square, ${ }^{*}$ M.S.S: Mean sum of square, $\mathrm{p}>0.05$ indicates non-significance, $\mathrm{p}<0.05$ indicates significance, ANOVA: Analysis of variance

Table 6: ANOVA of wetting time of ibuprofen fast-dissolving tablets formulated by employing starch glutamate

\begin{tabular}{|c|c|c|c|c|c|}
\hline Source of variation & d.f & Sum of squares & Mean S.S & Variance ratio & Result \\
\hline Replicates & 2 & 1.33 & 0.67 & 1.552 & $\mathrm{p}<0.05$ \\
\hline Treatments & 7 & 82266.00 & 11752.29 & 27422.00 & $\mathrm{p}<0.05$ \\
\hline Starch glutamate $(\mathrm{A})$ & 1 & 11528.17 & 11528.17 & 26899.06 & $\mathrm{p}<0.05$ \\
\hline Croscarmellose sodium (B) & 1 & 11792.67 & 11792.67 & 27516.22 & $\mathrm{p}<0.05$ \\
\hline Starch glutamate $\times$ Croscarmellose sodium $(\mathrm{AB})$ & 1 & 11008.17 & 11008.17 & 25685.72 & $\mathrm{p}<0.05$ \\
\hline Crospovidone (C) & 1 & 12788.17 & 12788.17 & 29839.06 & $\mathrm{p}<0.05$ \\
\hline Starch glutamate $\times$ Crospovidone (AC) & 1 & 11094.00 & 11094.00 & 25886.00 & $\mathrm{p}<0.05$ \\
\hline $\begin{array}{l}\text { Starch glutamate } \times \text { Croscarmellose } \\
\text { sodium } \times \text { Crospovidone }(A B C)\end{array}$ & 1 & 11266.67 & 11266.67 & 26288.89 & $\mathrm{p}<0.05$ \\
\hline Error & 14 & 6.00 & 0.43 & - & - \\
\hline Total & 23 & - & - & - & - \\
\hline
\end{tabular}

All the values are expressed as mean \pm SD, where $n=3$, SD: Standard deviation. d.f: Degree of freedom, *S.S: Sum of square, *M.S.S: Mean sum of square, p>0.05 indicates non-significance, $\mathrm{p}<0.05$ indicates significance, ANOVA: Analysis of variance

Table 7: ANOVA of water absorption ratio of ibuprofen fast-dissolving tablets formulated employing starch glutamate

\begin{tabular}{|c|c|c|c|c|c|}
\hline Source of variation & d.f & Sum of squares & Mean S.S & Variance ratio & Result \\
\hline Replicates & 2 & 0.000 & 0.000 & 0.000 & $\mathrm{P}>0.05$ \\
\hline Treatments & 7 & 8.915 & 1.274 & 178300.00 & $\mathrm{p}<0.05$ \\
\hline Starch glutamate (A) & 1 & 2.691 & 2.691 & 376794.65 & $\mathrm{p}<0.05$ \\
\hline Croscarmellose sodium (B) & 1 & 0.516 & 0.516 & 72236.27 & $\mathrm{p}<0.05$ \\
\hline Starch glutamate $\times$ Croscarmellose sodium $(\mathrm{AB})$ & 1 & 1.266 & 1.266 & 177293.49 & $\mathrm{p}<0.05$ \\
\hline Crospovidone (C) & 1 & 0.224 & 0.224 & 31316.19 & $\mathrm{p}<0.05$ \\
\hline Starch glutamate $\times$ Crospovidone $(\mathrm{AC})$ & 1 & 1.385 & 1.385 & 193872.15 & $\mathrm{p}<0.05$ \\
\hline Starch glutamate $\times$ Croscarmellose sodium $\times$ Crospovidone $(\mathrm{ABC})$ & 1 & 1.007 & 1.007 & 141031.85 & $\mathrm{p}<0.05$ \\
\hline Error & 14 & 0.0001 & 0.00001 & - & - \\
\hline Total & 23 & - & - & - & - \\
\hline
\end{tabular}

All the values are expressed as mean \pm SD, where $n=3$, SD: Standard deviation. d.f: Degree of freedom, *S.S: Sum of square, *M.S.S: Mean sum of square, p>0.05 indicates non-significance, $\mathrm{p}<0.05$ indicates significance, ANOVA: Analysis of variance

Table 8: ANOVA of dissolution efficiency in $\mathbf{5}$ min of ibuprofen fast-dissolving tablets formulated employing starch glutamate

\begin{tabular}{|c|c|c|c|c|c|}
\hline Source of variation & d.f & Sum of squares & Mean S.S & Variance ratio & Result \\
\hline Replicates & 2 & 7.31 & 3.66 & 2.546 & $\mathrm{P}>0.05$ \\
\hline Treatments & 7 & 16507.00 & 2358.14 & 1642.49 & $\mathrm{p}<0.05$ \\
\hline Starch glutamate (A) & 1 & 2281.50 & 2281.50 & 1589.10 & $\mathrm{p}<0.05$ \\
\hline Croscarmellose sodium (B) & 1 & 3337.04 & 3337.04 & 2324.31 & $\mathrm{p}<0.05$ \\
\hline Starch glutamate $\times$ Croscarmellose sodium $(\mathrm{AB})$ & 1 & 2124.40 & 2124.40 & 1479.68 & $\mathrm{p}<0.05$ \\
\hline Crospovidone (C) & 1 & 1683.38 & 1683.38 & 1172.50 & $\mathrm{p}<0.05$ \\
\hline Starch glutamate $\times$ Crospovidone (AC) & 1 & 1037.54 & 1037.54 & 722.66 & $\mathrm{p}<0.05$ \\
\hline $\begin{array}{l}\text { Starch glutamate } \times \text { Croscarmellose } \\
\text { sodium } \times \text { Crospovidone }(\mathrm{ABC})\end{array}$ & 1 & 927.53 & 927.53 & 646.04 & $\mathrm{p}<0.05$ \\
\hline Error & 14 & 20.10 & 1.44 & - & - \\
\hline Total & 23 & - & - & - & - \\
\hline
\end{tabular}

All the values are expressed as mean \pm SD, where $n=3$, SD: Standard deviation. d.f: Degree of freedom, *S.S: Sum of square, *M.S.S: Mean sum of square, p $>0.05$ indicates non-significance, $\mathrm{p}<0.05$ indicates significance, ANOVA: Analysis of variance 
The rate of drug dissolution of formulation F2 was comparable with the F4, which was prepared by employing $5 \%$ concentration of starch glutamate as a superdisintegrant.

ANOVA results of disintegration time (Table 5), wetting time (Table 6), water absorption ratio (Table 7), and dissolution efficiency in $5 \mathrm{~min}$

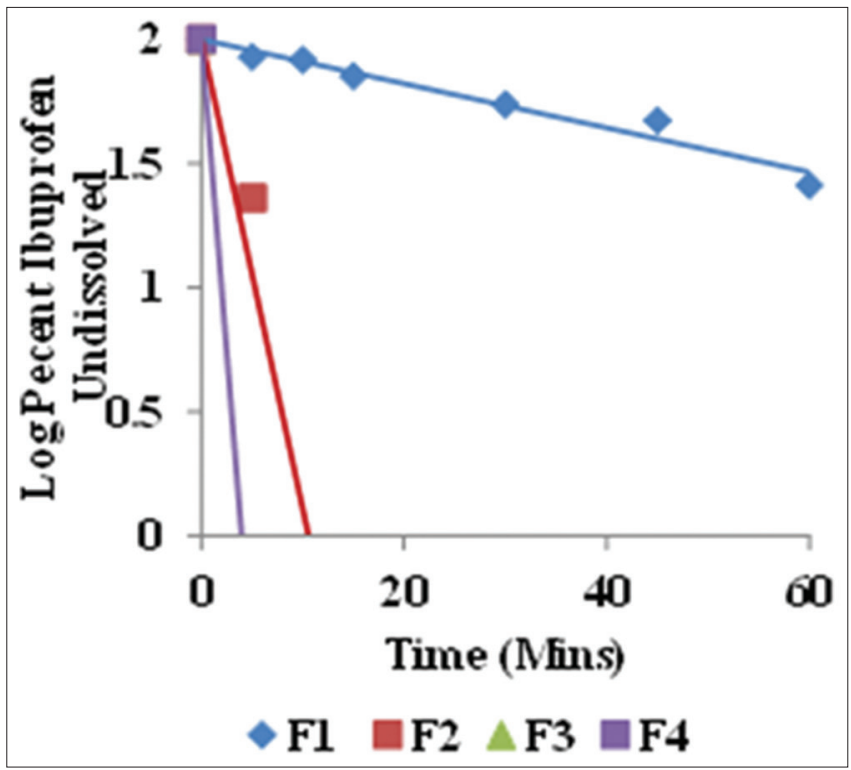

Fig. 6a: Time versus log percent drug undissolved plots for ibuprofen fast-dissolving tablets prepared by employing starch glutamate (F1-F4) $(n=3$, mean \pm standard deviation)

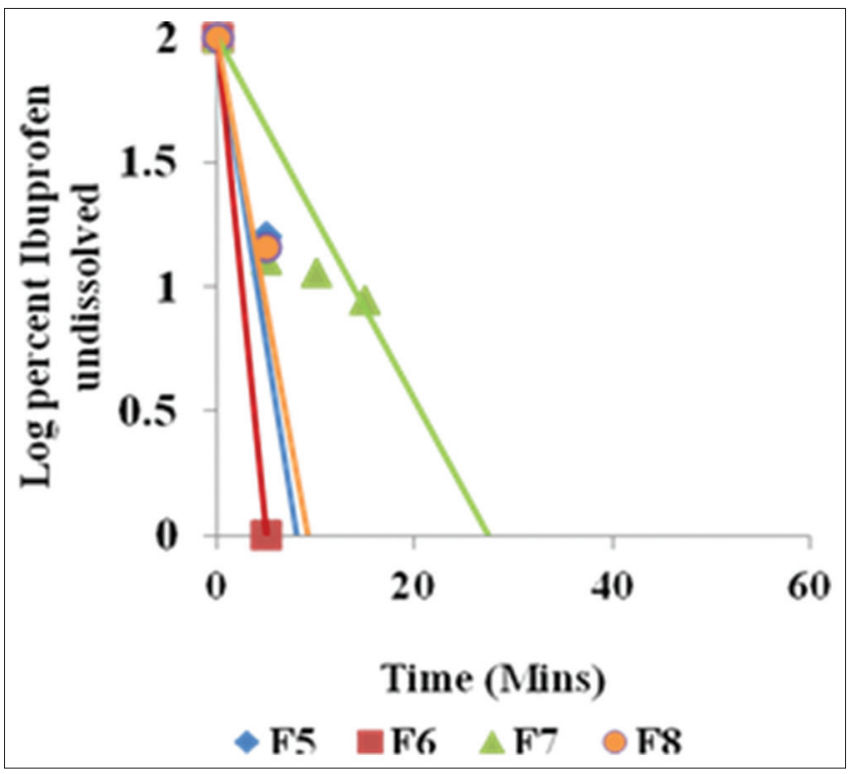

Fig. 6b: Time versus log percent drug undissolved plots for ibuprofen fast-dissolving tablets prepared by employing starch glutamate (F5-F8) (n=3, mean \pm standard deviation)

Table 9: Level of independent factor in $2^{3}$ factorial design

\begin{tabular}{lllll}
\hline Factors & & & \multicolumn{2}{l}{ Levels } \\
\cline { 5 - 5 } Ingredient & Code & & $\mathbf{L}_{\mathbf{1}}$ & $\mathbf{L}_{\mathbf{2}}$ \\
\hline Starch glutamate & $\mathrm{A}$ & & 0 & 5 \\
Croscarmellose sodium & $\mathrm{B}$ & & 0 & 5 \\
Crospovidone & $\mathrm{C}$ & & 0 & 5 \\
\hline
\end{tabular}

(Table 8) were given, and from these results it was concluded that significant effect was observed on the wetting time, water absorption ratio, disintegration time, and on dissolution efficiency in 5 min due to individual effects of starch glutamate (A), croscarmellose sodium (B), and crospovidone $(C)$ as well as combined effects of $\mathrm{AB}, \mathrm{BC}, \mathrm{AC}$, and $\mathrm{ABC}$.

\section{Factorial design}

Polynomial equation (Equations 1 and 2) indicates the effect of independent variables on the response variables. In the present study, ibuprofen fast-dissolving tablets were formulated using $2^{3}$ factorial design; it means three superdisintegrants starch glutamate (A), croscarmellose sodium (B), and crospovidone (C) at two different concentrations $(0 \%$ and $5 \%)$. Levels of individual factors in different fast-dissolving tablet formulation of ibuprofen are given in Tables 9 and 10 .

Polynomial equations

Percent dissolved in $5 \mathrm{~min}=+81.77+9.61 \mathrm{~A}+11.9 \mathrm{~B}+8.30 \mathrm{C}-10.0 \mathrm{AB}-6.52$ $\mathrm{AC}-13.94 \mathrm{BC}+6.09 \mathrm{ABC}(\mathrm{R} 2=1.000)$

Dissolution efficiency in $5 \mathrm{~min}=+39.26+5.21 \mathrm{~A}+6.29 \mathrm{~B}+4.19 \mathrm{C}-4.91$ $\mathrm{AB}-3.16 \mathrm{AC}-7.09 \mathrm{BC}+3.01 \mathrm{ABC}\left(\mathrm{R}^{2}=1.000\right)$

Polynomial equations of percent dissolved in $5 \mathrm{~min}$ and dissolution efficiency in $5 \mathrm{~min}$ indicate the interactions between the superdisintegrants and their relative response on the percent dissolved in $5 \mathrm{~min}$ and dissolution efficiency in $5 \mathrm{~min}$ by considering the magnitude of the coefficient and mathematical sign it carries (Positive or negative).

In the above polynomial equations correlation coefficient $\left(\mathrm{R}^{2}\right)$ value obtained as 1.000 which indicates a good fit.

Surface response plots and contour plots for the dissolution efficiency in $5 \mathrm{~min}$ and percent dissolve in $5 \mathrm{~min}$ are given as Figs. 7-12. From the polynomial equation, contour plots and surface plots following conclusions were drawn.

a) Interactions between the superdisintegrants, i.e., starch glutamate, croscarmellose sodium (AB) showed a positive effect on the percent dissolved in $5 \mathrm{~min}$ and dissolution efficiency in $5 \mathrm{~min}$ at a

Table 10: A transformed design for analysis of responses of ibuprofen fast-dissolving tablets

\begin{tabular}{llll}
\hline Formula code & A (\%) & B (\%) & C (\%) \\
\hline F1 & 0 & 0 & 0 \\
F2 & 5 & 0 & 0 \\
F3 & 0 & 5 & 0 \\
F4 & 5 & 5 & 0 \\
F5 & 0 & 0 & 5 \\
F6 & 5 & 0 & 5 \\
F7 & 0 & 5 & 5 \\
F8 & 5 & 5 & 5 \\
\hline
\end{tabular}

Table 11: Summary on pharmacokinetic parameters

\begin{tabular}{lll}
\hline $\begin{array}{l}\text { Pharmacokinetics } \\
\text { parameter }\end{array}$ & $\begin{array}{l}\text { Pure } \\
\text { ibuprofen (A) }\end{array}$ & $\begin{array}{l}\text { Optimized ibuprofen } \\
\text { fast dissolving tablet } \\
\text { formulation F2 employing } \\
\text { starch glutamate (B) }\end{array}$ \\
\hline $\mathrm{C}_{\text {max }}(\mu \mathrm{g} / \mathrm{ml})$ & 1.44 & 114 \\
$\mathrm{~T}_{\max }(\mathrm{h})$ & 4.0 & 1.0 \\
$\mathrm{AUC}_{0-8 \mathrm{~h}}(\mu \mathrm{g} \cdot \mathrm{h} / \mathrm{ml})$ & 9.815 & 471 \\
$\mathrm{AUC} \mathrm{C}_{0-\alpha}(\mu \mathrm{g} . \mathrm{h} / \mathrm{ml})$ & 34.345 & 497.6 \\
$\mathrm{BA}(\%)$ & 100 & 1448.8 \\
$\mathrm{~K}_{\mathrm{a}}\left(\mathrm{h}^{-1}\right)$ & 0.714 & 0.847 \\
$\mathrm{~K}_{\mathrm{el}}\left(\mathrm{h}^{-1}\right)$ & 0.0481 & 0.412 \\
$\left.\mathrm{MRT}^{\mathrm{h}} \mathrm{h}\right)$ & 0.99 & 0.97 \\
\hline
\end{tabular}




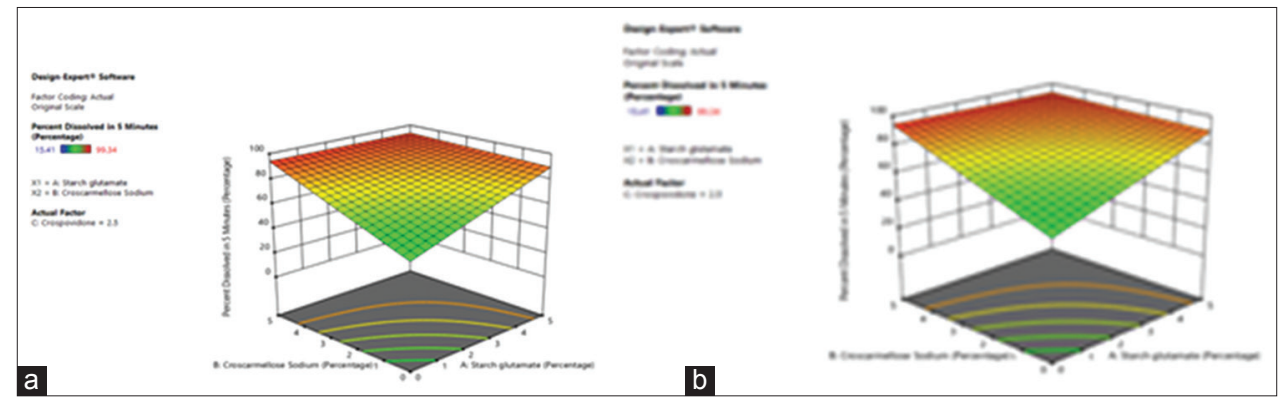

Fig. 7: (a) Response surface plot (b) contour plot of ibuprofen fast-dissolving tablets (Effect of starch glutamate and croscarmellose sodium on percent dissolved in $5 \mathrm{~min}$ )

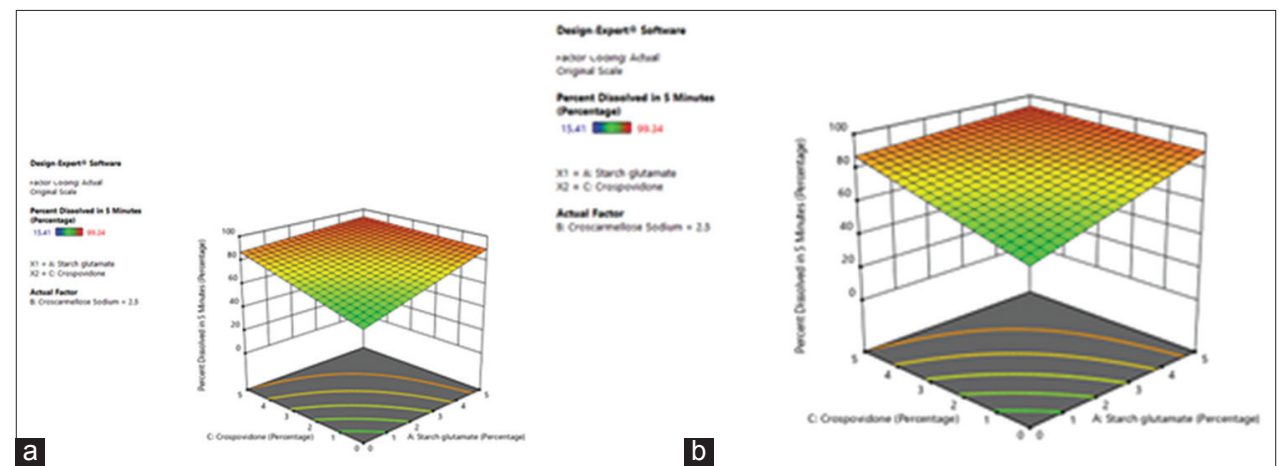

Fig. 8: (a) Response surface plot (b) contour plot of ibuprofen fast-dissolving tablets (Effect of starch glutamate and crospovidone on percent dissolved in 5 min)

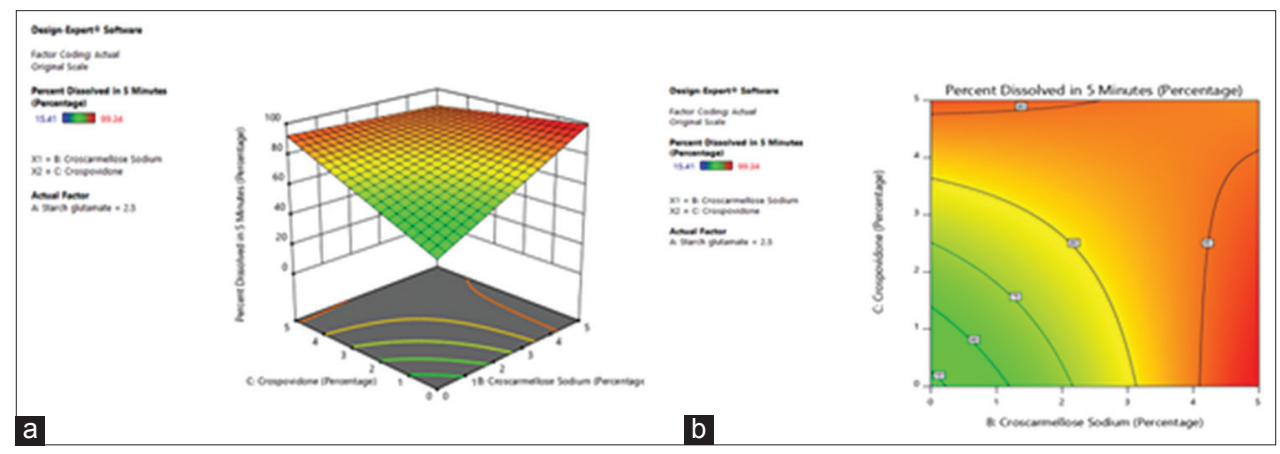

Fig. 9: (a) Response surface plot (b) contour plot of ibuprofen fast-dissolving tablets (Effect of crospovidone and croscarmellose sodium on percent dissolved in 5 min)

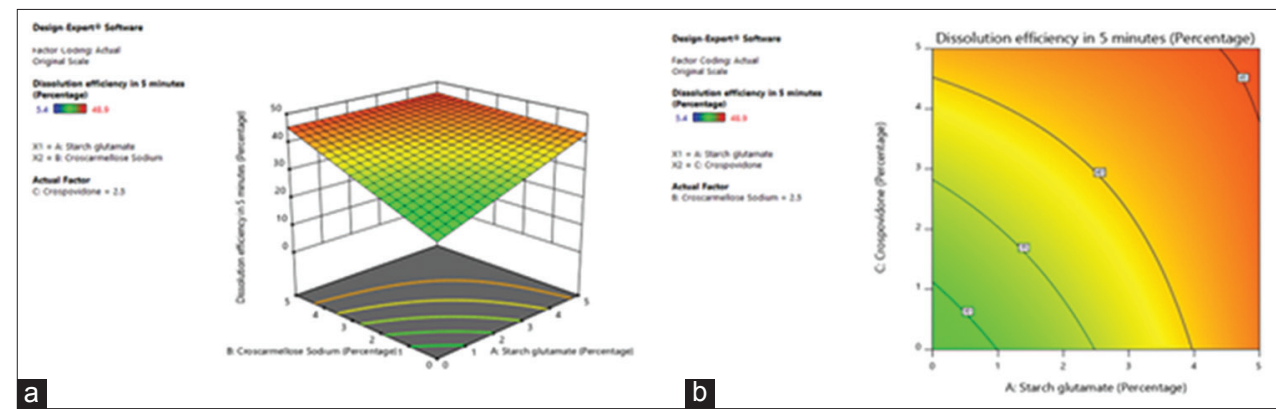

Fig. 10: (a) Response surface plot (b) contour plot of ibuprofen fast-dissolving tablets (Effect of starch glutamate and croscarmellose sodium on dissolution efficiency in $5 \mathrm{~min}$ )

concentration range of 4-5\%. The contour plots which were drawn between the starch glutamate and croscarmellose sodium $(\mathrm{AB})$ were found to be linear.

b) Interactions between the superdisintegrants, i.e., starch glutamate, crospovidone (AC) showed a positive effect on the percent dissolved in $5 \mathrm{~min}$ and dissolution efficiency in $5 \mathrm{~min}$ at a concentration range of $4-5 \%$. The contour plots which were drawn between the starch glutamate and crospovidone (AC) were found to be linear.

c) Interactions between the superdisintegrants, i.e., croscarmellose sodium, crospovidone (BC) showed a positive effect on the percent 


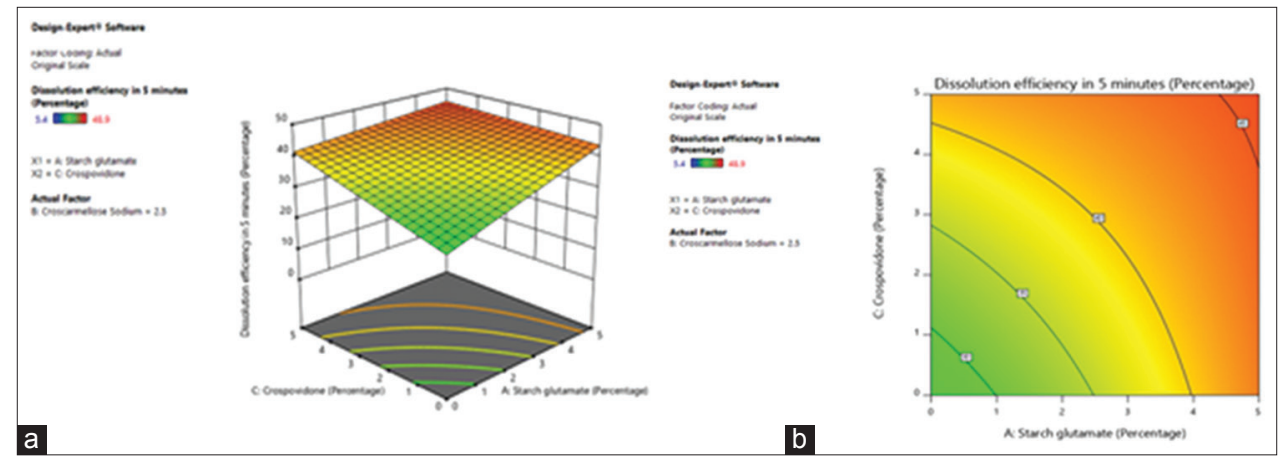

Fig. 11: (a) Response surface plot (b) contour plot of ibuprofen fast-dissolving tablets (Effect of starch glutamate and crospovidone on dissolution efficiency in 5 min)

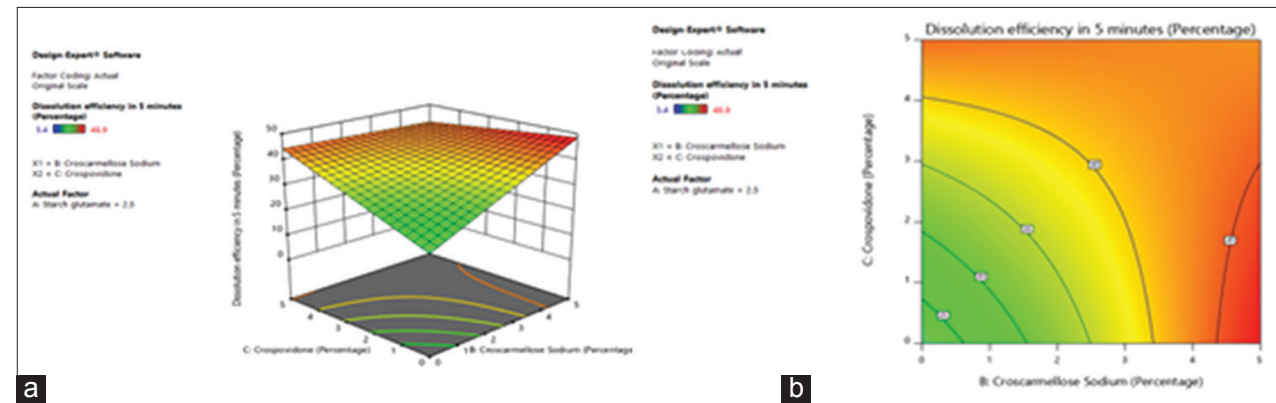

Fig. 12: (a) Response surface plot (b) contour plot of ibuprofen fast-dissolving tablets (Effect of crospovidone and croscarmellose sodium on dissolution efficiency in 5 min)

Table 12: Physical properties of optimized ibuprofen fast-dissolving tablets formulation before and after storage during the stability studies

\begin{tabular}{lllllll}
\hline Formulation & $\begin{array}{l}\text { Hardness } \\
\left(\mathbf{k g} / \mathbf{c m}^{2} \mathbf{~} \mathbf{n} \pm \mathbf{S D}\right.\end{array}$ & $\begin{array}{l}\text { Friability (\%) } \\
\mathbf{n} \pm \mathbf{S D}\end{array}$ & $\begin{array}{l}\text { Drug content } \\
\mathbf{( m g / t a b ) ~} \mathbf{n} \pm \mathbf{S D}\end{array}$ & $\begin{array}{l}\text { Wetting time (s) } \\
\mathbf{n} \pm \mathbf{S D}\end{array}$ & $\begin{array}{l}\text { Water absorption } \\
\text { ratio (\%) } \mathbf{n} \pm \mathbf{S D}\end{array}$ & $\begin{array}{l}\text { Disintegration } \\
\text { time (s) } \mathbf{n} \pm \mathbf{S D}\end{array}$ \\
\hline $\begin{array}{l}\text { Ibuprofen (F2) } \\
\text { (Before stability) }\end{array}$ & $3.9 \pm 0.01$ & $0.12 \pm 0.011$ & $199.21 \pm 0.31$ & $9 \pm 0.58$ & $2.22 \pm 0.001$ & $21.3 \pm 1.5$ \\
$\begin{array}{l}\text { Ibuprofen (F2) } \\
\text { (After stability) }\end{array}$ & $3.9 \pm 0.03$ & $0.11 \pm 0.012$ & $199.32 \pm 0.13$ & $9 \pm 0.05$ & $2.23 \pm 0.003$ & $21.5 \pm 1.2$ \\
\hline
\end{tabular}

Table 13: Cumulative percent drug dissolved of ibuprofen fast-dissolving tablets, F2 before and after storage for 6 months during the stability study testing

\begin{tabular}{lll}
\hline Time (min) & $\begin{array}{l}\text { Cumulative percent of ibuprofen released } \\
(\bar{X} \pm \text { SD })\end{array}$ \\
\cline { 2 - 3 } & Before storage & After $\mathbf{6}$ months storage \\
\hline 5 & $77.1 \pm 2.43$ & $77.5 \pm 1.21$ \\
10 & $99.1 \pm 1.15$ & $99.6 \pm 1.44$ \\
15 & - & - \\
30 & - & - \\
45 & - & - \\
60 & - & - \\
\hline
\end{tabular}

SD: Standard deviation

dissolved in $5 \mathrm{~min}$ and dissolution efficiency in 5 min at a concentration range of $4-5 \%$. The contour plots which were drawn between the croscarmellose sodium, crospovidone (BC) for dissolution efficiency in 5 min showed a non-linear relationship between the croscarmellose sodium, and crospovidone (BC) whereas the contour plots drawn between the croscarmellose sodium, crospovidone (BC) four percent dissolved in 5 min showed a linear relation between them.

\section{Optimum formula}

The formulation F4 containing 5\% concentration of starch glutamate and $5 \%$ concentration of crospovidone showed highest percent drug dissolution and more dissolution efficiency in $5 \mathrm{~min}$, whereas formulation F2 containing the single superdisintegrant, i.e., 5\% concentration of starch glutamate also showed comparable percent drug dissolution and dissolution efficiency in $5 \mathrm{~min}$ as like formulation F4. Hence, formulation F2 was considered as an optimum formulation with single novel superdisintegrant, i.e., starch glutamate, which was economical compared to other formulations.

\section{In vivo studies}

In vivo studies have been performed on the male Wistar rats for the optimum formulation $\mathrm{F} 2$ and the pure drug to know the pharmacokinetic parameters of the optimized ibuprofen fast dissolving tablets (F2). The results of the pharmacokinetic parameters are summarized in Table 11.

From the results of the pharmacokinetic parameters, it was concluded that the optimized formulation (F2) ibuprofen fast-dissolving tablet attained peak plasma concentration within a short period of time and showed more drug absorption with increased in relative bioavailability as compared to the pure drug.

\section{Stability studies}

Shelf life of optimized ibuprofen fast-dissolving tablets was established by performing stability studies at accelerated conditions as per the ICH and WHO stability guidelines by storing samples at temperatures of $40 \pm 2^{\circ} \mathrm{C}$ and $75 \pm 5 \%$ RH for 6 months. Samples were analyzed before and after storage of 6 months. Results for the stability studies are given in the following Tables 12 and 13 and Fig. 13. 


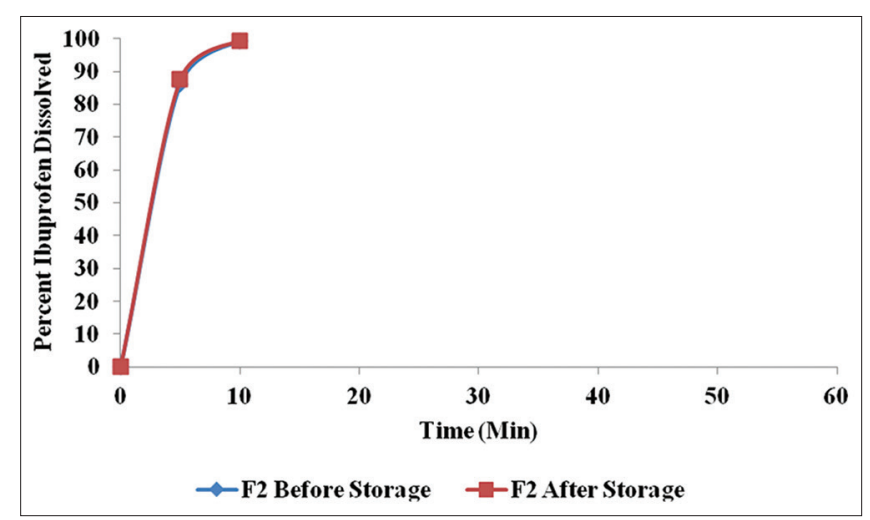

Fig. 13: Cumulative percent drug dissolved of ibuprofen fastdissolving tablets, F2 before and after storage for 6 months during the stability testing

\section{CONCLUSION}

In the present work, dissolution efficiency and bioavailability of ibuprofen drug were increased by formulating it into fast-dissolving tablets by employing starch glutamate, a novel superdisintegrant. From the drug-excipient compatibility studies, it was concluded that prepared starch glutamate was not showing interactions with the drug and it was compatible. Superdisintegrant property of the starch glutamate was evaluated by formulating the fast dissolving tablets of the ibuprofen at different proportions of various superdisintegrants, including the starch glutamate. Prepared ibuprofen fast-dissolving tablets were evaluated for post-compression properties and in vitro and in vivo drug release characteristics. From the results of the tablet evaluation tests, it was known that all the ibuprofen fast-dissolving tablet formulations passing the official pharmacopeial tablet evaluation tests. Pharmacokinetic parameters of the optimized ibuprofen fastdissolving tablet formulation F2 attained peak plasma concentration in a short period of time and showed increased in an absorption rate with increased relative bioavailability of the drug. Optimized ibuprofen fastdissolving tablet formulation F2 stability was established by performing stability studies at accelerated stability conditions for 6 months, and it was found to stable.

Hence, the prepared starch glutamate can be used as a superdisintegrant in the formulation of fast-dissolving tablets to increase the solubility as well as bioavailability of the poorly soluble drugs.

\section{AUTHORS' CONTRIBUTIONS}

Experimental design, guidance, supervision, review work, experimental work, development and optimization of the formulations, interpretation of result, and writing of this manuscript were done by both Dr. R. Santosh Kumar and Mrs. Sahithi Mudili. Both authors read and approve the final manuscript.

\section{CONFLICTS OF INTEREST}

We declare that we have no conflicts of interest.

\section{REFERENCES}

1. Abualhasan M, Assali M, Jaradat N, Tarayra R, Hamdan A, Ardah R, et al. Synthesis and formulation of ibuprofen pro-drugs for enhanced transdermal absorption. Int J Pharm Pharm Sci 2015;7:352-4.

2. Chauhan K, Solanki R, Sharma S. A review on fast dissolving tablets. Int J App Pharm 2018;10:1-7.

3. Mannem V, Suryadevara V, Doppalapudi S. Formulation and evaluation of telmisartan solid dispersions using entada scandens seed starch and poloxamer-188 as superdisintegrants. Asian J Pharm Clin Res 2018;9:474-81.

4. Khanam N, Alam MD, Ali QM, Siddiqui A. A review on optimizaiton of drug delivery system with experimental designs. Int J App Pharm 2018;10:7-12

5. Roy A. Orodispersible tablets: A review. Asian J Pharm Clin Res 2016;9:19-26.

6. Mohan A, Sangeetha G. In vitro-in vivo evaluation of fast-dissolving tablets containing solid dispersion of oxcarbazepine. Int J Pharm Pharm Sci 2016;8:124-31

7. Caretensen JT. Guidelines for Drug Stability. Principles and Practices. $3^{\text {rd }}$ ed. New York: Marcel Dekkar; 2005. p. 252-5.

8. Kumar RS, Yagnesh TN, Kumar VG. Optimisation of ibuprofen fast dissolving tablets employing starch xanthate using $2^{3}$ factorial design. Int J App Pharm 2017;9:51-9. 